\title{
Pengaruh Pupuk Organik Cair dan Pupuk Majemuk Terhadap Pertumbuhan dan Produksi Jagung Ketan (Zea mays var. ceratina)
}

\section{Effect of Liquid Organic Fertilizer and Mixed Fertilizer on Plants and Waxy Corn Production (Zea mays var. ceratina)}

\section{Christiforus R. Lamakoma1, Jacob R. Patty ${ }^{2, *}$, Martha Amba ${ }^{2}$}

\author{
${ }^{1}$ Program Studi Agroteknologi, Fakultas Pertanian, Universitas Pattimura, Jl. I. M. Putuhena, Kampus Poka Ambon, \\ 97233
}

${ }^{2}$ Jurusan Budidaya Pertanian, Fakultas Pertanian, Universitas Pattumura, Jl. I. M. Putuhena, Kampus Poka Ambon, 97233

E-mail Penulis Korespondensi: jacobrichardpatty@gmail.com

\begin{abstract}
This study aimed to analyze the benefits of providing liquid and organic fertilizers and to determine the dosage of the liquid organic fertilizer and mixed fertilizers on growth and yield of waxy corn (Zea mays var. ceratina). The study was conducted in August to November 2017 in the Wailete, Wayame Village, Teluk Ambon Subdistrict, with alluvial soil types. The experiment used factorial experiments in a randomized block design with three replications. The first factor was liquid organic fertilizer with four levels, namely: $C O=$ Control, $C 1=10 \mathrm{~mL} / \mathrm{L}$ of water, $C 2=20 \mathrm{~mL} / \mathrm{L}$ of water, C3 $=30 \mathrm{~mL} / \mathrm{L}$ of water. The second factor is NPK DGW $(M)$ mixed fertilizer with three levels, namely: MO =Control, $M 1=$ $2.5 \mathrm{~g} /$ plant, $M 2=5 \mathrm{~g} /$ plant. The parameters observed were plant height, leaf number, ear length, dry ear weight, $100 \mathrm{dry}$ seed weight, dry kernel weight. The data from the study were analyzed using the analysis of variance method and continued with a mean difference test, according to Duncan Multiple Range Test. The treatment of liquid organic fertilizer significantly affected the observation parameters at 2, 3 and 4 weeks after planting (WAP), including ear length, dry ear weight, 100 seeds dry weight, dry kernels weight; however, there were no significant effects on plant height at 5 and 6 WAP and leaf number at 2, 4 and 6 WAP. The mixed fertilizer treatment had significant effects on plant height at 2, 3, 4, 5 and 6 MST, leaf number at 2, 4 and 6 WAP, ear length, dry ear weight, 100 seeds dry weight and dry kernel weight.
\end{abstract}

Keywords: compound fertilizer, liquid organic fertilizer, waxy corn

\section{ABSTRAK}

Penelitian ini bertujuan untuk menganalisis manfaat pemberian pupuk organik cair dan majemuk serta menetapkan dosis pemberian pengaruh pupuk organik cair dan pupuk majemuk terhadap pertumbuhan dan produksi tanaman jagung ketan (Zea mays Ceratina). Penelitian dilaksanakan pada bulan Agustus sampai dengan November 2017 di Dusun Wailete, Desa Wayame, Kecamatan Teluk Ambon Baguala, dengan jenis tanah aluvial. Percobaan menggunakan percobaan faktorial dalam rancangan acak kelompok dengan tiga ulangan. Faktor pertama pupuk organik cair dengan empat taraf, yaitu: $\mathrm{C}_{0}=$ Kontrol, $\mathrm{C}_{1}=10 \mathrm{~mL} / \mathrm{L}$ air, $\mathrm{C}_{2}=20 \mathrm{~mL} / \mathrm{L}$ air, $\mathrm{C}_{3}=30 \mathrm{~mL} / \mathrm{L}$ air. Faktor ke dua pupuk majemuk NPK DGW (M) dengan tiga taraf, yaitu : $\mathrm{M}_{0}=\mathrm{Kontrol}, \mathrm{M}_{1}=2,5 \mathrm{~g} / \mathrm{tanaman}, \mathrm{M}_{2}=5 \mathrm{~g} /$ tanaman. Parameter yang diamati yaitu tinggi tanaman, jumlah daun, panjang tongkol, berat tongkol kering, berat kering 100 biji, berat Pipilan kering. Data hasil penelitian dianalisis dengan menggunakan metode analisis of varians dan dilanjutkan dengan uji beda rataan menurut jarak berganda Duncan. Perlakuan pupuk oragnik cair berpengaruh nyata pada parameter tinggi tanaman pada 2, 3 dan 4 MST, panjang tongkol, berat tongkol kering, berat kering 100 biji, berat Pipilan kering, berpengaruh tidak nyata pada tinggi tanaman 5 dan 6 MST dan jumlah daun pada 2, 4 dan 6 MST. Perlakuan pupuk majemuk memberikan pengaruh yang nyata pada parameter tinggi tanaman pada 2, 3, 4, 5 dan 6 MST, jumlah daun pada 2, 4 dan 6 MST, panjang tongkol, berat tongkol kering, berat kering 100 biji dan berat pipilan kering.

Kata kunci: jagung ketan, pupuk majemuk, pupuk organik cair

\section{PENDAHULUAN}

Jagung sampai saat ini masih merupakan komoditi strategis kedua setelah padi karena Jagung merupakan salah satu komoditi serealia yang mempunyai nilai ekonomis tinggi. Di Indonesia jagung merupakan salah satu komoditi pertanian sumber karbohidrat yang digemari oleh masyarakat kerena rasa yang manis, 
mengandung karbohidrat, protein, vitamin yang tinggi serta kandungan lemak yang rendah. Jagung mengandung kadar gula yang relatif tinggi, biasanya dipanen muda untuk dikonsumsi. Bagi petani komoditas ini merupakan harapan, karena nilai jualnya yang cukup tinggi dan dapat dipasarkan sampai ke supermarket atau restoran. Selain sebagai sumber pangan (food) dan pakan (feed), jagung juga banyak digunakan sebagai bahan baku energi (fuel) serta bahan baku industri lainnya yang kebutuhan tiap tahunnya terus mengalami peningkatan (Hermanto et al., 2009).

Produksi Jagung pada tahun 2017 cenderung mengalami peningkatan 27,95 ribu ton (BPS, 2017). Peningkatan tersebut disebabkan oleh perluasa areal tanam yang juga didukung oleh perbaikan penerapan teknologi budidaya tanaman jagung. Upaya peningkatan produktivitas usaha tani jagung sangat bergantung pada kemampuan penyediaan dan penerapan teknologi sistim budidaya yang benar-benar sesuai anjuran seperti penggunaan benih bermutu, pengaturan jarak tanam, pengairan, pemberantasan hama dan penyakit, serta penggunaan pupuk (Sudadi dan Suryanto, 2001).

Jagung ketan merupakan salah satu jenis jagung yang memiliki karakter khusus yaitu pati dalam bentuk $100 \%$ amilopektin, memiliki rasa manis, pulen, dan penampilan menarik yang tidak dimiliki jagung lain sehingga banyak disukai oleh masyarakat. Namun jagung ketan kurang populer, khususnya di masyarakat kota karena kurang dipromosikan dan belum mendapat perhatian sungguh-sungguh untuk dikembangkan. Hal ini dapat mengakibatkan hilangnya sumber plasma nutfah jagung ketan khususnya yang berasal dari daerah Bolaang Mongondow (Mahendradatta dan Tawali, 2008),

Pemberian pupuk yang tepat jenis, tepat dosis dan tepat waktu dalam pengembangan budidaya jagung ketan diharapkan dapat memperbaiki kesuburan tanah serta meningkatkan hasil panen secara kuantitatif maupun kualitatif. Lingga dan Marsono (2001), menyatakan bahwa pupuk merupakan kunci dari kesuburan tanah karena berisi satu atau lebih unsur untuk menggantikan unsur yang telah diserap tanaman. Jenis pupuk yang dapat digunakan adalah pupuk organik, pupuk organic cair dan pupuk anorganik. Puuk organik yang dihasilkan dari pemanfaatan limbah pertanian yang berasal dari sisa-sisa hasil pertanian seperti tumbuhan dan hewan/ternak dapat digunakan untuk memenuhi kebutuhan hara.

Pupuk organik cair (POC) yaitu pupuk organik dalam sediaan cair; mengandung unsur hara berbentuk larutan yang sangat halus sehingga sangat mudah diserap oleh tanaman, sekalipun oleh bagian daun atau batangnya. Aplikasi POC dilakukan dengan cara disemprotkan pada daun atau batang tanaman. Sumber bahan baku pupuk organik tersedia dimana saja dengan jumlah yang melimpah yang semuanya dalam bentuk limbah, baik limbah rumah tangga, rumah makan, pasar pertanian, peternakan, maupun limbah organik jenis lain (Nassaruddin dan Rosmawati, 2011).

Pupuk organik cair mampu memberikan nilai tambah bagi tanaman pada saat pertumbuhan dan perkembangan tanaman. Disamping itu, pupuk ini juga bermanfaat dalam memperbaiki tanah dan mengandung mikroorganisme yang dapat mengurangi serangan penyakit pada tanaman yang dipupuk. Tanaman dapat memanfaatkan semaksimal mungkin unsur hara dari pupuk melalui minimalisasi pencucian dan penguapan. Salah satu upaya yang dilakukan untuk menghindari penguapan dan pencucian pupuk adalah melakukan pemupukan secara berulang dengan mengatur frekuensi pemberian pada tanaman.

Damanik et al. (2011) menyatakan bahwa keberhasilan pemupukan juga ditentukan oleh faktor waktu pemupukan. Waktu pemberian haruslah tepat, sehingga saat tanaman membutuhkan unsur hara tersebut tersedia untuk diabsorbsi tanaman. Pemberian pupuk yang terlalu awal akan menyebabkan pupuk cepat hilang dari areal perakaran tanaman karena terjadi pencucian atau penguapan sehingga tidak tersedia bagi tanaman. Hasil peneltian Puspadwi et al. (2016) menujukkan bahwa pemberian pupuk organik cair dan NPK, 1 NPK, 1 POC, 2 POC, 1 POC + 1 NPK, 1 POC + 1/2 NPK, 2 POC $+1 \mathrm{NPK}, 2 \mathrm{POC}+1 / 2 \mathrm{NPK}$ tidak memberikan pengaruh yang nyata pada 3 MST dan 4 MST terhadap pertumbuhan dan hasil tanaman jagung manis (Zea mays L. var. Rugosa Bonaf).

Pupuk NPK DGW (N 15\% - P 15\% - K 15\%) merupakan pupuk majemuk cepat tersedia yang cukup dikenal saat ini. Bentuk pupuk NPK yang sekarang beredar di pasaran adalah pengembangan dari bentukbentuk NPK lama yang kadarnya masih rendah. Kadar NPK yang banyak beredar adalah 16-16-16 dan 8-20-15. Kadar lain yang tidak terlalu umum beredar adalah 6-1215, 12-12-12 atau 20-20-20, 15-15-15. Tiga tipe pupuk NPK tersebut juga sangat populer karena kadarnya cukup tinggi dan memadai untuk menunjang pertumbuhan tanaman (Damanik et al., 2011).

\section{METODELOGI PENELITIAN}

\section{Bahan Dan Alat Penelitian}

Penelitian dilaksanakan pada bulan Agustus sampai dengan November 2017 di Dusun Wailete, Desa Wayame, Kecamatan Teluk Ambon, dengan jenis tanah aluvial.

\section{Bahan}

Benih jagung ketan, pupuk majemuk (NPK DGW), dan pupuk organik cair.

\section{Metode Penelitian}

Penelitian menggunakan rancangan acak kelompok. Faktorial dengan dua faktor yang diteliti, yaitu Faktor I: pemberian pupuk organik cair dengan empat taraf yaitu kontrol (tanpa perlakuan), $10 \mathrm{~mL} / \mathrm{L}$ air, $20 \mathrm{~mL} / \mathrm{L}$ air, $30 \mathrm{~mL} / \mathrm{L}$ air. Faktor II: pemberian pupuk majemuk NPK DGW (M) dengan tiga taraf, yaitu: kontrol (tanpa perlakuan), 2,5 g/tanaman, dan 5 
g/tanaman. Jumlah kombinasi perlakuan $4 \times 3=12$ kombinasi yaitu: jumlah ulangan 3 ulangan, jumlah plot percobaan 36 plot, jarak antar tanaman $30 \mathrm{~cm} \times 50 \mathrm{~cm}$, luas petakan $2 \mathrm{~m} \times 1 \mathrm{~m}$, jarak antar plot $30 \mathrm{~cm}$, jarak antar ulangan $50 \mathrm{~cm}$.

\section{Pelaksanan Penelitian}

\section{Persiapan Areal}

Areal yang digunakan sebagai tempat penanaman dibersihkan dari gulma, sisa-sisa tanaman, dan sampah sampah yang ada, kemudiantanah dicangkul sedalam $30 \mathrm{~cm}$ lalu dihaluskan dan diratakan. Selanjutnya dibuat plot-plot percobaan dan diantaranya dibuat parit drainase. Tanah yang telah dicangkul digemburkan dibuat plot-plot percobaan dengan ukuran petakan $2 \mathrm{~m}$ $\times 1$ m dengan jarak antar plot $30 \mathrm{~cm}$, jarak antar ulangan $50 \mathrm{~cm}$ dan jarak antar tanaman $30 \mathrm{~cm} \times 50 \mathrm{~cm}$. Sehingga setiap plot terdiri dari 12 tanaman jagung.

Tahapan-Tahapan pemberian dan waktu aplikasi pupuk organik dan pupuk majemuk dengan intesitas curah hujan

Tahapan pemberian pupuk oganik cair terbagi atas 3 tahap yaitu tahapan pertama tanggal 11 Agustus 2017 dengan konsentrasi yang diberikan ke tanah bersamaan dengan pemberian pupuk dasar 0 (tanpa perlakuan), 10 (5 mL POC), 20 (10 mL POC), 30 (15 mL POC). Tahapan kedua diberikan pada saat tanaman masih dalam proses vegetatif yaitu tanggal 17 September 2017, 10 (tanpa perlakuan), 10 (2,5 mL POC), 10 (5 mL POC), $10(7,5 \mathrm{~mL}$ POC) tahapan ketiga diberikan tanggal 15 oktober, tanaman memasuki fase generatif yaitu 0 (tanpa perlakuan), 10 (2,5 mL POC), 20 (5 mL POC), 30 (7,5 $\mathrm{mL}$ POC). Pemberiaan pupuk pupuk majemuk diberikan hanya satu kali pemberian yaitu tanggal 3 september 2017, 0 (tanpa perlakuan), 2,5 $\mathrm{g}$ dan $5 \mathrm{~g}$.

\section{Penanaman}

Sebelum biji jagung ditanam terlebih dahulu biji direndam dalam air hangat selama satu jam dan kemudian ditanam di lapangan penanaan dilakukan secara tugal dengan meletakkan dua butir jagung pada setiap lubang tanam pada kedalaman $3 \mathrm{~cm}$ dengan jarak tanam $30 \mathrm{~cm} \times 50 \mathrm{~cm}$. Setelah biji dimasukkan ke dalam lubang lalu ditutup dengan tanah.

\section{Pemeliharaan}

Penyiraman, penjarangan, penyulaman, pembumbunan, pengendalian hama dan penyakit.

\section{Pemanenan}

Dilakukan pada saat tanaman berumur 85-90 hari setelah tanam (HST). Tanaman jagung dapat di panen jika buah jagung sudah matang fisiologis dengan ciri morfologi rambut berwarna cokelat, kelobot berwarna hijau tua, daun tanaman telah menguning dan telah memenuhi kriteria untuk dipanen.

\section{Parameter Pengamatan}

Tinggi tanaman $(\mathrm{cm})$, jumlah daun (helai), panjang tongkol $(\mathrm{cm})$, berat tongkol kering ( $\mathrm{g} /$ tanaman), berat 100 biji kering per tongkol atau per tanaman, berat pipilan kering (g/tanaman).

\section{HASIL DAN PEMBAHASAN}

\section{Hasil Kombinasi Pupuk organik Cair dan Pupuk Majemuk}

Hasil analisis keragaman menunjukkan bahwa perlakuan konsentrasi pupuk organik cair dan pupuk majemuk memberikan pengaruh nyata pada fase generatif atau hasil produksi, yaitu pada parameter panjang tongkol, berat tingkol kering, berat kering 100 biji, berat pipilan kering. pada fase vegetatif atau pertumbuhan tanaman pemberian pupuk organik cair tidak nyata pada paramter tinggi tanaman (5 MST, 6 MST) dan paramter jumlah daun (2 MST, 4 MST, 6 MST) sebaliknya perlakuan pupuk majemuk pada fase vegetatif memberikan hasil yang nyata pada parameter tinggi tanaman dan paramter jumlah daun. kedua faktor yang diberikan ketanaman yaitu pupuk organik cair dan pupuk majemuk tidak terjadinya interaksi pada semua paramter yang diamati yaitu tinggi tanaman, jumlah daun, panjang tongkol, berat tongkol kering, berat kering 100 biji dan berat pipilan kering, tetapi faktor yang diberikan lebih bersifat tunggal.

\section{Tinggi Tanaman}

Parameter pertumbuhan vegetatif pertama yang diamati ialah Tinggi tanaman dihitung dari pangkal batang hingga ruas batang terakhir sebelum bunga. Tinggi tanaman merupakan ukuran tanaman yang sering diamati sebagai indikator pertumbuhan maupun sebagai parameter untuk mengukur pengaruh lingkungan atau perlakuan yang diterapkan karena tinggi tanaman merupakan ukuran paling mudah dilhat.

Bedasrkan hasil uji, pemberian pupuk organik cair dan pupuk majemuk memberikan hasil yang berbeda dapat dilihat pada Tabel 2. Pemberian pupuk organik cair pada tanaman jagung umur 2 MST, 3 MST memberikan hasil yang sangat nyata dan pada umur 4 MST nyata, sebaliknya pada umur 5 MST, 6 MST pemberian pupuk organik cair memberikan hasil yang tidak nyata. Pemberian pupuk majemuk memberikan pengaruh yang sangat nyata pada 4 MST, 5 MST, 6 MST dan memberikan pengaruh yang nyata pada umur 2 MST dan 3 MST. Tanaman akan tumbuh dengan baik apabilah kebutuhan unsur hara dibutuhkan oleh tanaman terpenuhi untuk merangsang pertumbuhan tinggi tanaman. pada umur 2 MST, 3 MST, 4 MST tanaman jagung memasuki fase V3-V5 (jumlah daun terbuka sempuna 3-5) pada fase ini akar seminal sudah mulai berhenti tumbuh. Akar seminal adalah akar yang berkembang dari radikula dan embrio. Pertumbuhan akar seminal akan melambat setelah plumula muncul kepermukaan tanah dan pertumbuhan akar seminar akan berhenti pada fase V3. 
Akar adventif adalah akar yang semula berkembang dari buku di ujung monokotil, kemudian set akar adventif menyebar dari tiap buku secara berurutan dan terus keatas antara 7-10 buku semuanya dibawah permukaan tanah. akar adventif berperan dalam mengambil unsur hara dan air didalam tanah yang diperlukan dalam jumlah yang banyak. diduga pemberian pupuk organik cair tahapan pertama 11 Agustus 2017 yaitu C0 (tanpa perlakuan), C1 (5 mL POC), C2 (10 mL POC), C3 (15 mL POC) yang diberikan bersamaan dengan pemberian pupuk kompos sebagai pupuk pupuk dasar dan pemberian pupuk majemuk 2 minggu sesudah penanaman tanggal 3 September 2017, M0 (tanpa perlakuan), M1 (2,5 g), M2(5 g) mampu menyediakan unsur hara yang dibutuhkan oleh tanaman, selain itu fungsi dan peran pupuk kompos yang diberikan sebagai pupuk dasar juga mempengaruhi pertumbuhan tinggi tanaman umur 2 MST, 3 MST, 4 MST. Menurut (Made, 2010) kandungan unsur hara pupuk vermikompos yang lengkap dan tersedia secara slow release akan membantu menambah dan memenuhi kebutuhan unsur hara yang di butuhkan tanaman ketika pupuk anorganik yang diberikan hanya setengah dosis yang dianjurkan.

Pada umur 5 MST dan 6 MST tanaman memasuki fase akhir V10 dan fase V11-Vn (jumlah daun terbuka sempurna 11- daun terakhir 15-18 ) fase ini berlangsung pada saat tanaman berumur 33-50 hari setelah berkecambah. Tanaman tumbuh dengan cepat, air dan unsur hara dalam jumlah yang cukup sangat dibutuhkan pada fase ini. tanaman yang kekurangan air dan unsur hara akan mempengaruhi pertumbuhan tanaman. Diduga pemberian tahapan pertama pupuk organik cair diberikan sudah habis terserap oleh tanaman pada umur 2 MST, 3 MST, 4 MST. walupun pemberian tahapan kedua pupuk organik cair tanggal 17 September 2017, C0 (tanpa perlakuan), C1 (2,5 mL POC), C2 (5 mL POC), C3 (7,5 $\mathrm{mL}$ POC) belum mampuh memenuhi kebutuhan unsur hara yang dibutuhkan tanaman umur 5 MST dan 6 MST. hal ini di karena pada saat aplikasi tahapan kedua yang diberikan ke daun, belum bisa diserap oleh tanaman secara maksimal, dikarenakan salah satu kekurangan dari pupuk organik cair adalah mudah tercuci, saat aplikasi, ada terjadinya curah hujan walaupun kapasitas curah hujan yang turun terbilang rendah yaitu $21 \mathrm{~mm}$. Sebaliknya pemberian pupuk majemuk memberikan hasil yang nyata pada umur tanaman 5 MST dan 6 MST diduga kandungan N $15 \%$ - P $15 \%$ - k 15\% yang terdapat didalam pupuk majemuk bisa mencukupi kebutuhan hara yang dibutuhkan tanaman. Menurut Hidayati (2009), pupuk N, P, K sangat dibutuhkan untuk pertumbuhan tanaman terutama dalam merangsang pembentukan tinggi tanaman dan pembesaran diameter batang.

Tabel 2 Perlakuan pupuk organik cair dan pupuk majemuk terhadap hasil tinggi tanaman

\begin{tabular}{cccccc}
\hline \multirow{2}{*}{ Perlakuan } & \multicolumn{5}{c}{ Tinggi tanaman } \\
\cline { 2 - 5 } & 2 MST & 3 MST & 4 MST & 5 MST & 6 MST \\
\hline $\mathbf{0}$ & $31,99 \mathrm{c}$ & $56,01 \mathrm{c}$ & $95,93 \mathrm{a}$ & 129,13 & 165,14 \\
$\mathbf{1 0}$ & $34,25 \mathrm{~b}$ & $58,91 \mathrm{~b}$ & $97,39 \mathrm{a}$ & 132,54 & 176,05 \\
$\mathbf{2 0}$ & $35,11 \mathrm{~b}$ & $64,20 \mathrm{a}$ & $100,83 \mathrm{a}$ & 133,89 & 173,55 \\
$\mathbf{3 0}$ & $38,52 \mathrm{a}$ & $69,47 \mathrm{a}$ & $104,07 \mathrm{~b}$ & 137,26 & 173,56 \\
$\mathbf{0}$ & $32,77 \mathrm{~b}$ & $57,42 \mathrm{~b}$ & $93,71 \mathrm{~b}$ & $125,85 \mathrm{~b}$ & $176,37 \mathrm{~b}$ \\
$\mathbf{2 , 5}$ & $34,91 \mathrm{~b}$ & $61,90 \mathrm{a}$ & $100,87 \mathrm{a}$ & $135,00 \mathrm{a}$ & $185,29 \mathrm{a}$ \\
\hline $\mathbf{5}$ & $37,23 \mathrm{a}$ & $67,11 \mathrm{a}$ & $104,08 \mathrm{a}$ & $138,76 \mathrm{a}$ & $\mathrm{a}$ \\
\hline
\end{tabular}

Keterangan: Angka-angka yang diikuti huruf yang sama tidak berbeda nyata pada uji jarak berganda Duncan 0,05. $\mathrm{C}=$ Pupuk Organik cair, $\mathrm{M}=$ Pupuk Majemuk.

\section{Jumlah Daun}

Parameter pertumbuhan vegetatif kedua yang diamati ialah jumlah daun. Pengamatan jumlah daun sangat diperlukan karena selain sebagai indikator pertumbuhan parameter jumlah daun juga butuhkan sebagai data penujang untuk menjelaskan proses pertumbuhan jumlah daun tanaman jagung umur 2 MST, 4 MST dan 6 MST. Bedasarkan hasil uji, pemberian pupuk organik cair dan pupuk majemuk memberikan hasil yang berbeda dapat dilihat pada Tabel 4.3. pemberian pupuk organik cair memberikan hasil yang tidak nyata pada semua umur tanaman yaitu 2 MST, 4 MST, 6 MST. Sebaliknya pada perlakuan pupuk majemuk memberikan hasil yang sangat nyata pada 4 MST, 6 MST dan memberikan hasil yang nyata pada 2 MST. Semakin panjang batang atau semakin tinggi tanaman, serta semakin banyak ruas yang terbentuk sehingga jumlah daun makin banyak (Tabel 2 dan 3). Batang tersusun dari ruas yang merentang diantara bukubuku sebagai tempat pembentukan daun, jumlah daun merupakan peubah untuk menentukan pertumbuhan tanaman karena daun berperan dalam proses fotosintesis.

Pengaruh pemberian pupuk organik cair tidak nyata pada parameter tinggi tanaman 5 MST, 6 MST mempengaruhi pada pertumbuhan jumlah daun umur 6 MST. Diduga ketersedian unsur hara N, P dan K yang terdapat pada pupuk organik cair yang diberikan pada tahapan kedua tanggal 17 September 2017, C0 (tanpa perlakuan), C1 (2,5 mL POC), C2 (5 mL POC), C3 (7,5 $\mathrm{mL}$ POC) belum mampuh menambah kebutuhan unsur hara yang dibutuhkan oleh tanaman. Fahrudin (2009) jumlah daun dipengaruhi oleh unsur hara $\mathrm{N}, \mathrm{P}$ dan $\mathrm{K}$ yang ada didalam tanah. intensitas curah hujan $219 \mathrm{~mm}$ yang terjadi pada tanggal 2 September 2017 mempengaruhi ketersedian unsur harayang ada didalam 
tanah dan mengakibatkan pertumbuhan jumlah daun yang berkurang. Hanafi (2002) mengemukakan bahwa pencucian hara tersebut adalah kehilangan bahan organik dan bahan anorganik pada permukaan tanah atau top soil oleh aktivitas pelarutan air, termasuk hujan, kabut dan embun. Hal tersebut mempengaruhi berkurangnya ketersedian pupuk $\mathrm{N}, \mathrm{P}$ dan $\mathrm{K}$ yang ada didalam tanah untuk membantu proses penambahan jumlah daun umur 2 MST dan 4 MST. Menurut Sutedjo (2002), pertumbuhan tanaman membutuhkan banyak unsur $\mathrm{N}$.
Unsur $\mathrm{N}$ berguna untuk merangsang pertumbuhan tanaman secara keseluruhan, merangsang pertumbuhan vegetatif dan berfungsi untuk sintesa asam amino dan protein dalam tanaman. Novizan (2002) menambahkan bahwa nitrogen juga dibutuhkan untuk membentuk senyawa penting seperti klorofil, asam nukleat, dan enzim. Karena itu, nitrogen dibutuhkan dalam jumlah besar pada setiap tahap pertumbuhannya, khususnya pada tahap pertumbuhan vegetatif, seperti pembentukan tinggi tanaman dan jumlah daun.

Tabel 3. Perlakuan pupuk organik cair dan pupuk majemuk terhadap hasil jumlah daun

\begin{tabular}{cccc}
\hline \multirow{2}{*}{ Perlakuan } & \multicolumn{3}{c}{ Jumlah Daun } \\
\cline { 2 - 4 } & $\mathbf{2 ~ M S T}$ & 4 MST & 6 MST \\
\hline $\mathbf{1 0}$ & $8,69 \mathrm{a}$ & $10,20 \mathrm{a}$ & $13,24 \mathrm{a}$ \\
$\mathbf{2 0}$ & $8,81 \mathrm{a}$ & $10,39 \mathrm{a}$ & $13,67 \mathrm{a}$ \\
$\mathbf{3 0}$ & $8,57 \mathrm{a}$ & $10,33 \mathrm{a}$ & $13,62 \mathrm{a}$ \\
$\mathbf{0}$ & $8,52 \mathrm{a}$ & $10,43 \mathrm{a}$ & $12,74 \mathrm{~b}$ \\
$\mathbf{2 , 5}$ & $8,38 \mathrm{~b}$ & $9,68 \mathrm{~b}$ & $13,74 \mathrm{c}$ \\
$\mathbf{5}$ & $8,62 \mathrm{a}$ & $10,50 \mathrm{c}$ & $14,11 \mathrm{a}$ \\
\hline
\end{tabular}

Keterangan : Angka-angka yang diikuti huruf yang sama tidak berbeda nyata pada uji jarak berganda Duncan 0,05. C = Pupuk Organik cair, $\mathrm{M}=$ Pupuk Majemuk.

\section{Pengaruh Pemberian Pupuk Organik Cair Dan Pupuk Majemuk Terhadap Parameter Panjang Tongkol, Berat Tongkol Kering, Berat Kering 100 Biji Dan Berat Pipil Kering}

Fase pertumbuhan generatif yang diamati ialah parameter panjang tongkol, berat tongkol kering, berat kering 100 biji dan berat pipil kering. Paramter Berat tongkol kering, Berat kering 100 biji, berat pipil kering di pengaruhi oleh parameter panjang tongkol. Dapat diasumsikan bahwa semakin panjang suatu tongkol tanaman, akan mempengaruhi pada Berat tongkol kering, Berat kering 100 biji dan berat pipil kering.Bedasrkan hasil uji, pemberian pupuk organik cair dan pupuk majemuk memberikan hasil rata-rata yang sangat nyata dan nyata dapat dilihat pada Tabel 4. pemberian pupuk organik cair memberikan pengaruh yang sangat nyata pada parameter panjang tongkol, berat tongkol kering, berat kering 100 biji dan memberikan hasil yang nyata pada parameter berat pipilan kering. Pelakuan pupuk Majemuk memberikan pengaruh yang sangat nyata pada semua fase pengamatan generatif yaitu parameter panjang tongkol, berat tongkol kering, berat kering 100 biji dan berat pipilan kering. Pemberian tahapan ketiga yang diberikan kedaun tangal 15 oktober $2017 \mathrm{CO}$ (tanpa perlakuan), C1 (2,5 mL POC), C2 (5 mL POC), C3 (7,5 $\mathrm{mL}$ POC) tanaman telah memasuki fase R1 (silking), tahap silking diawali oleh munculnya rambut dari dalam tongkol yang tertutup kelobot. Pada fase ini serapan $\mathrm{N}$ dan $\mathrm{K}$ sangatlah cepat sementara $\mathrm{K}$ sudah hampir lengakap. Menurut Desmawita (2010) mengatakan bahwa pemupukan melalui daun tidak dimaksud untuk memenuhi seluruh unsur hara yang dibutuhkan oleh tanaman, dengan demikian pemupukan melalui daun hanyalah pelengkap dari pemupukan biasa dengan maksud untuk memperbaiki kualitas hasil karena penambahan unsur hara melalui daun dapat melengkapi kekurangan hara tertentu yang dibutuhkan oleh tanaman tersebut. Wibisono dan Basri (1993) menyatakan bahwa tanaman dapat tumbuh dan berproduksi dengan sempurna bila unsur hara yang diperlukan mencukupi. jika suatu tanaman kekurangan kandungan unsur hara pupuk, laju pertumbuhan tanaman tersebut akan lambat dan tidak optimal dalam produksi suatu tanaman (Dwidjosaputro, 1997). Tanaman jagung membutuhkan nitrogen sepanjang hidupnya dan sangat efektif dalam penggunaan amonium meskipun sebagian besar diambil dalam bentuk nitrat (Sudjana $d k k$., 1991).Novriani (2010), menambahkan bahwa P pada masa generatif dialokasikan pada proses pembentukan biji atau buah tanaman. Lebih lanjut Mapegau (2010), menyatakan bahwa $P$ berfungsi sebagai sumber energi dalam berbagai reaksi metabolisme tanaman berperan penting dalam peningkatan hasil serta memberikan banyak fotosintat yang didistribusikan ke dalam biji sehingga hasil biji tanaman jagung meningkat. karena di antara fungsi fosfor yang dikemukakan Isnaini (2006) bahwa mempercepat pembentukan buah dan biji serta meningkatkan produksi. Ukuran buah dan kualitas buah pada vase generatif akan dipengaruhi oleh ketersediaan unsur $\mathrm{K}$, sedangkan $\mathrm{P}$ berperan dalam pembentukan buah dan bunga (Novizan, 2002). diduga pemberian pupuk organik cair tangal 15 Oktober 2017 mampu melengkapi kebutuhan pupuk dibutuhkan tanaman dalam fase generatif. 
Tabel 4 Perlakuan pupuk organik cair dan pupuk majemuk terhadap hasil produki

\begin{tabular}{ccccc}
\hline \multirow{2}{*}{ Perlakuan } & \multicolumn{4}{c}{ Rata-Rata Hasil Produksi } \\
\cline { 2 - 5 } & $\begin{array}{c}\text { Panjang } \\
\text { Tongkol }\end{array}$ & $\begin{array}{c}\text { Berat Tongkol } \\
\text { Kering }\end{array}$ & $\begin{array}{c}\text { Berat Kering 100 } \\
\text { biji }\end{array}$ & Berat Pipilan Kering \\
\hline C0 & $4,08 \mathrm{c}$ & $31,67 \mathrm{c}$ & $29,10 \mathrm{c}$ & $86,56 \mathrm{~b}$ \\
C1 & $5,24 \mathrm{~b}$ & $45,78 \mathrm{~b}$ & $27,99 \mathrm{~b}$ & $95,00 \mathrm{~b}$ \\
C2 & $5,85 \mathrm{~b}$ & $58,89 \mathrm{~b}$ & $29,11 \mathrm{c}$ & $100,67 \mathrm{a}$ \\
C3 & $7,00 \mathrm{a}$ & $83,33 \mathrm{a}$ & $42,81 \mathrm{a}$ & $84,00 \mathrm{c}$ \\
M0 & $14,10 \mathrm{c}$ & $129,17 \mathrm{c}$ & $22,68 \mathrm{c}$ & $98,08 \mathrm{~b}$ \\
M1 & $15,63 \mathrm{~b}$ & $153,33 \mathrm{~b}$ & $33,81 \mathrm{~b}$ & $114,83 \mathrm{a}$ \\
\hline
\end{tabular}

Keterangan: Angka-angka yang diikuti huruf yang sama tidak berbeda nyata pada uji jarak berganda Duncan 0.05. $\mathrm{C}=$ Pupuk Organik cair, $\mathrm{M}=$ Pupuk Majemuk

\section{Interaksi Pupuk Organik Cair dan Pupuk Majemuk}

Hasil penelitan menunjukkan bahwa perlakuan pupuk organik cair dan pupuk majemuk tidak saling berinteraksi. Data hasil penelitian menunjukkan bahwa pengaruh kedua faktor yang diteliti lebih bersifat tunggal, karena salah satunya faktor dipengaruhi oleh iklim (curah hujan) yang berdampak kepada interaksi kedua faktor dan tidak memberikan pengaruh yang bersinergi atau tidak sama.

\section{KESIMPULAN}

Hasil analisis Pupuk organik cair dan pupuk majemuk terhadap pertumbuhan dan produksi jagung ketan (Z. mays ceratina) dapat disimpulkan bahwa:

1. Konsentrasi pupuk organik cair berpengaruh sangat nyata terhadap variabel pengamatan tinggi tanaman umur 2 MST dan 3 MST, panjang tongkol, berat tongkol kering dan berat kering 100 biji, berpengaruh nyata terhadap tinggi tanaman $4 \mathrm{mst}$ dan berat pipilan kering dan berpengaruh tidak nyata terhadap variabel pengamatan tinggi tanaman 5 mst dan 6 mst serta jumlah daun semua umur tanam.

2. konsentrasi pupuk majemuk berpengaruh sangat nyata terhadap produksi tanaman serta tinggi tanaman 4 mst, 5 mst dan 6 mst dan jumlah daun 4 mst serta 6 mst namun menunjukan pengaruh yang nyata terhadap tinggi tanaman $2 \mathrm{mst}$ dan $3 \mathrm{mst}$ serta jumlah daun $2 \mathrm{mst}$

3. tidak terdapat interaksi yang nyata antara konsentrasi pupuk organik cair dan pupuk majemuk terhadap semua variabel pertumbuhan dan produksi tanaman jagung yang diamati.

\section{DAFTAR PUSTAKA}

Badan Pusat Statistika, 2017. Data Badan Pusat Statistika Tentang Jagung. http://www.bps.go.id/tnmn_pgn.php.

Dwidjosaputro, D. 1986 Pengantar Fisiologis Tumbuhan. Jakarta: Gramedia.

Damanik, M.M.B., E.H. Bachtiar, Fauzi, Sarifuddin, dan H. Hamidah. 2011. Kesuburan Tanah dan
Pemupukan. USU Press, Medan. hal. 262

Desmawita. 2010. Pengaruh Pemberian Beberapa Konsentrasi Pupuk Organik Cair Lengkap Bio Sugih dan Media Tanam Terhadap Pertumbuhan Bibit Gambir (Uncaria gambir Roxb). Skripsi. Padang. Fakultas Pertanian Universitas Andalas. $39 \mathrm{Hal}$.

Fahrudin, F. 2009. Budidaya Caisim (Brassica juncea L.) Menggunakan Ekstrak Teh dan Pupuk Kascing. Skripsi. Fakultas Pertanian. Universitas Sebelas Maret. Surakarta.

Hermanto, D.W., E. Sadikin, dan Hikmat. 2009. Deskripsi varietas unggul palawija 1918 -2009. Puslitbangtan Pangan. Balitbang Pertanian.

Hidayati, N. 2009. Efektivitas Pupuk Hayati pada berbagai Lama Simpan terhadap Pertumbuhan Tanaman Padi(Oryza sativa) dan Jagung (Zea mays). Skripsi. Departemen Biologi, Fakultas Matematika dan Ilmu Pengetahuan Alam, Institut Pertanian Bogor. Bogor.

Hanafi, I. 2002. Unsur Hara yang Hilang Akibat Pencucian di Bawah Tegakan Pinus (Piinus merkusii) Agathis (Agathis loranthifolia) dan Puspa (Schima waliichii) di DAS Cipereu Hutan Pendidikan Gunung Walat Sukabumi. Skripsi. Fakultas Kehutanan. Institut Pertanian Bogor, Bogor.

Isnaini, M . 2006. Pertanian Organik Untuk Keuntungan Ekonomi dan Kelestarian Bumi. Yogyakarta: Kreasi Wacana.

Lingga, P. dan Marsono. 2001. Pedoman Teknik Penggunaan Pupuk. Jakarta: Penebar Swadaya. $130 \mathrm{hlm}$.

Mapegau. 2010. Pengaruh pupuk N dan P terhadap pertumbuhan dan hasil tanaman jagung. Jurnal Penelitian Universitas Jambi Seri Sains. Hal. 3336.

Mahendradatta, M. dan A.B. Tawali. 2008. Jagung dan Diversifikasi Produk Olahannya. Makassar: Masagena Press.

Made, U. 2010. Respons bebagai populasi tanaman jagung manis (Zea mays Saccrata Strut.) terhadap pemberian pupuk urea. Agroland Jurnal IlmuIlmu Pertanian 17: 138-143. 
Nasaruddin, dan Rosmawati. 2011. Pengaruh pupuk organik cair (POC) hasil fermentasi daun gamal, batang pisang dan serabut kelapa terhadap pertumbuhan bibit kakao. Jurnal Agrisistem 7: 29-37.

Novizan. 2002. Petujuk Pemumpukan Yang Efektif. Jakarta: Agromedia Pustaka. 130 hal.

Novriani, 2010. Alternatif pengelolaan unsur hara $\mathrm{P}$ (Fosfor) pada budidaya jagung. Jurnal Agronobis 2: 33-36.

Soemantri, S. dan Tohari. 2001. Pengelolaan Lahan Sawah Tadah Hujan Untuk Berkelanjutan Sistem Produksi. Prosiding Seminar Nasional Budidaya Tanaman Pangan Berwawasan Lingkungan. Puslitbang Tanaman Pangan. Bogor.

Sudadi, M. dan W.A. Suryanto. 2001. Terobosan Teknologi Pemupukan dalam Era Pertanian Organik. Budidaya Tanaman Pangan, Hortikultura dan Perkebunan. Yogyakarta: Penerbit Kanisius. 78 p.
Puspadewi, S., W. Sutari, dan Kusumiyati. 2016. Pengaruh konsentrasi pupuk organik cair (POC) dan dosis pupuk N, P, K terhadap pertumbuhan dan hasil tanaman jagung manis (Zea mays L. var Rugosa Bonaf) kultivar Talenta. Jurnal Kultivasi 15: 208-216.

Sanjaya, K. 2016. Pengaruh pemberian urine sapi dan pupuk npk terhadap komponen produksi tanaman jagung (Zea mays Saccharata Sturt). JOM Faperta 3: 1-13.

Sutedjo, M.M. 2002. Pupuk dan Cara Pemupukan Edisi Revisi. Jakarta: Rineka Cipta.

Sudjana, A., A. Rifin, dan M. Sudjadi. 1991. Jagung. Buletin Teknik No. 3. Badan Penelitian dan Pengembangan Pertanian Balai Pertanian Tanaman Pangan Bogor. Jl. Tentara Pelajar 3 A Bogor.

Wibisino, A. dan M. Basri. 1993. Pemanfaatan Limbah Organik Untuk Kompos. Jakarta: Penebar Swadaya. 